\title{
Distribution of 'water' in the lithospheric mantle of the Carpathian-Pannonian region and its effect on rheology
}

\author{
NÓRA LIPTAI ${ }^{1,2}$, LEVENTE PATKÓ $^{1,3}$, THOMAS P. \\ LANGE $^{1,3}$, LÁSZLÓ E. ARADI ${ }^{3}$, MÁRTA BERKESI ${ }^{1,3}$, \\ CSABA SZABÓ ${ }^{2,3}$, ISTVÁN J. KOVÁCS ${ }^{1,2}$
}

${ }^{1}$ MTA CSFK Lendület Pannon LitH $_{2}$ Oscope Research Group, Budapest-Sopron, Hungary, liptai.nora@csfk.mta.hu ${ }^{2}$ Geodetic and Geophysical Institute, Research Centre for Astronomy and Earth Sciences, Sopron, Hungary

${ }^{3}$ Lithosphere Fluid Research Lab, Eötvös Loránd University, Budapest, Hungary

In the lithospheric mantle, 'water' can be present either as molecular $\mathrm{H}_{2} \mathrm{O}$ in fluids or melts, or as structurally bound hydroxyl in volatile-bearing (e.g., pargasite) or nominally anhydrous (olivine, pyroxenes) minerals (NAMs). Where pargasite is stable (up to $1050-1150^{\circ} \mathrm{C}$ or $\sim 3 \mathrm{GPa}$ [1]), it acts as the major reservoir for 'water', whereas in its absence, 'water' is mainly stored in NAMs. In the latter case, it can significantly influence the rheology of the upper mantle due to the effect of hydrolytic weakening.

In the Carpathian-Pannonian region, a Neogene extensional basin system, mantle xenoliths are brought to the surface by late Miocene - Pleistocene alkali basalts. Xenolith localities include the eastern and western marginal areas with subductional environment, and central areas strongly affected by lithospheric thinning. While xenoliths from the marginal localities contain more 'water' (both as pargasite and in NAMs), the central localities are significantly dryer, which can be related to decreased water activity during the extension [2]. We calculated effective viscosity and electrical resistivity for the xenoliths, and the results imply that these values both are about half an order of magnitude higher in the lithospheric mantle of the dryer central regions than those of the more 'wet' marginal regions, making the latter rheologically weaker. This may be a general feature for extensional basins bounded by subduction zones.

\section{References:}

[1] Green, D. H., Hibberson, W. O., Kovács, I., \& Rosenthal, A. (2010), Nature, 467(7314), 448-451.

[2] Patkó, L., Liptai, N., Kovács, I. J., Aradi, L. E., Xia, Q.-K., Ingrin, J., Mihály, J., O’Reilly, S. Y., Griffin, W. L., Wesztergom, V. \& Szabó, C. (2019). Chemical Geology, 507, 23-41. 